\title{
Teotônio das Alagoas: o menestrel da abertura
}

\author{
Marly Motta \\ Fundação Getulio Vargas (FGV-RJ)
}

Quem é esse viajante

Quem é esse menestrel

Que espalha esperança

E transforma sal em mel?

Quem é esse saltimbanco

Falando em rebelião

Como quem fala de amores

Para a moça do portão?

Quem é esse que conhece

Alagoas e Gerais

E fala a língua do povo

Como ninguém fala mais?

Quem é esse?

De quem essa ira santa

Essa saúde civil

Que tocando a ferida

Redescobre o Brasil?

Quem é esse peregrino

Que caminha sem parar?

Quem é esse meu poeta

Que ninguém pode calar?

Quem é esse?

\section{Introdução}

Quando fui convidada pelo Senado para escrever o perfil parlamentar de Teotônio Vilela ${ }^{1}$, a primeira imagem que me veio à memória foi a do homem magro que, chapéu na cabeça e bengala na mão, subia com dificuldade os 
degraus que levavam ao palco do teatro da UERJ onde uma platéia inquieta, da qual eu fazia parte, aguardava seu discurso. Em 1983, apesar do câncer, Teotônio andou por todo o país, defendendo a realização imediata de eleições diretas para presidente da República.

Pode-se considerar que Teotônio ocupa um lugar secundário na memória nacional em relação a outros personagens - civis como Tancredo Neves e Ulysses Guimarães; e militares, como a dupla Geisel-Golbery -, alçados à condição de figuras centrais do processo de redemocratização no Brasil. A hipótese que defendo nesse trabalho é que a peculiar trajetória política de Teotônio Vilela é um dos elementos centrais para se entender a transição democrática no Brasil a partir de 1975, quando o então senador da Arena assumiu a condição de porta-voz do desejo do presidente Geisel em favor da 'distensão política'. O argumento principal que sustenta essa hipótese é a 'dualidade' que, a meu ver, marcou a presença de Teotônio no cenário imprevisível e instável da abertura política no Brasil. O que se pretende comprovar é que essa 'dualidade', que ele frequentemente se atribuiu, ao mesmo tempo em que definiu seu perfil político, fez dele uma figura decisiva no delicado e incerto processo de transição democrática no Brasil.

$\mathrm{O}$ artigo está estruturado em três partes. Na primeira, procurarei responder à pergunta quem é esse?, mote da música que arrebatou multidões na campanha das diretas. Usineiro, empresário do açúcar e do álcool, Teotônio conseguiu conciliar essa atividade empresarial com uma firme atuação em favor de operários e posseiros. Ao mesmo tempo, precisou combinar a defesa dos interesses regionais com uma inserção no cenário nacional. Mesmo durante seu segundo mandato no Senado (1975-82), quando as questões nacionais tomaram a maior parte dos seus discursos, Teotônio não deixou de reafirmar sua condição de alagoano, de nordestino.

A segunda parte do texto focará a 'dualidade' que também se manifestou na atuação política de Teotônio, não limitada à esfera parlamentar na qual estava formalmente inserido. Movido por uma ambição taxada de 'quixotesca', Teotônio conseguiu espaço em outras tribunas - universidades, associações de classe, sindicatos - para divulgar suas ideias. Com um pé na sociedade política e outro na sociedade civil, pôde assim reconstruir laços de entendimento e cimentar alianças que se mostraram fundamentais no processo de abertura política.

\section{Maracanan}


Finalmente, analisaremos a comoção nacional provocada pela morte de Teotônio em 27 de novembro de 1983. Ao enfeixar dimensões pessoais e coletivas, a grandiosidade do evento veio mostrar que a política, ao contrário do que muitos pensam, não se faz apenas no campo das soluções concretas e realizáveis. É no terreno dos sonhos, esperanças e crenças, particularmente fértil nos momentos de reinício vividos pelas sociedades, que figuras como Teotônio Vilela são capazes de representar as aspirações e os valores maiores da nação.

\section{Quem é esse?}

Ao contrário de outros políticos, cuja origem regional constitui-se em elemento definidor de inserção no panorama nacional, Teotônio era à época, e ainda hoje é, considerado a antítese do político alagoano. Nada parece mais distante do "defensor dos direitos humanos e sociais", do "propagandista das liberdades democráticas", do que a imagem de violência e arbitrariedade associada ao exercício da política nesse pequeno estado nordestino ${ }^{2}$.

Teotônio Vilela nasceu no dia 28 de maio de 1917, em Viçosa das Alagoas, filho do dono do engenho Mata Verde. Depois de uma breve passagem pelo Rio de Janeiro (1937-40), de onde voltou sem o pretendido diploma de doutor, comprou as terras do Sabalangá, onde começou sua vida de produtor de cana-de-açúcar. Em 1947, juntando a família em uma cooperativa, levantou recursos junto ao Instituto do Açúcar e do Álcool (IAA) e ao Banco do Brasil para montar a Usina Boa Sorte. ${ }^{3}$

Foi na condição de usineiro que Teotônio ingressou na política local, ao ser eleito, em 1954, pela UDN, para a Assembléia Legislativa de Alagoas. Derrotado em sua pretensão de ser reeleito, conquistou, seis anos depois, em 1960, o cargo de vice-governador na chapa encabeçada por Luiz Cavalcante (UDN/PTN/PL). Em 1964, Teotônio apoiou o movimento militar que derrubou o governo constitucional de João Goulart. Foi, no entanto, ameaçado de cassação em virtude das relações de amizade que mantinha com os dois mais notórios comunistas de Alagoas. ${ }^{4}$ Nas eleições de novembro de 1966 , marcadas pela recém extinção dos partidos até então existentes e pela introdução do bipartidarismo, Teotônio conseguiu seu primeiro mandato senatorial. Pela sigla da Arena, onde se abrigou boa parte dos antigos udenistas, 
Teotônio formou, com Arnon de Mello e com o amigo Rui Palmeira, a bancada alagoana no Senado.

Membro de um grupo de senadores arenistas da antiga UDN considerados liberais - Milton Campos, Mem de Sá, Daniel Krieger, Gilberto Marinho, entre outros -, Teotônio foi calado pelo AI-5, de dezembro de 1968. A partir de então, usaria o poder de sua oratória na defesa dos interesses da agroindústria açucareira alagoana, em particular, e do Nordeste, em geral. ${ }^{5}$

Seria a defesa de 'um programa brasileiro de energia', o Proálcool, que acabaria por levar Teotônio a uma audiência com o presidente Geisel, em março de 1975, considerada o marco inaugural da sua atuação em prol da distensão. No entanto, desde 1973, Teotônio vinha retomando os temas políticos em seus discursos. A princípio muito sutilmente, quando, em abril, em um discurso de homenagem aos novos cardeais - dom Paulo Evaristo Arns, da arquidiocese de São Paulo, e dom Avelar Brandão Vilela, seu irmão, arcebispo de Salvador e primaz do Brasil - se referiu ao empenho necessário para "restaurar o corpo institucional do país na melhor forma de direito". 6 Em agosto, dentro das comemorações do sesquicentenário do Poder Legislativo no Brasil, Teotônio aproveitou a oportunidade de tal celebração para "pedir a volta do Estado de direito". ${ }^{7}$ O aparte do vice-líder do governo, senador Eurico Rezende, não demorou: "No que tange à rogativa de V. Exa. a respeito do Estado de direito, nele nós nos encontramos. Quem não se encontra são as tribos e as cubatas africanas". Em resposta, Teotônio sinalizou o caminho que pretendia seguir, caso fosse reeleito nas eleições de novembro de 1974. Discordando da orientação de seu partido, a Arena governista, preferia apostar nas probabilidades, se arriscar no imprevisível, 'carregar a história':

As grandes decisões políticas nunca nasceram de rigorosa combinação de meios que autorizassem tranquilamente a sua deflagração. Os pontos altos da história foram alcançados, em grande parte, pela garra do gênio, pela ousadia das probabilidades, pela aventura do espírito de luta. Quando alguém é impulsionado pela época a tomar uma decisão, já se disse que carrega a história. ${ }^{8}$

A posse do presidente Geisel em 15 de março de 1974, e sobretudo o seu apelo à 'imaginação criadora' dos políticos, gerou um clima otimista, toldado,

\section{Maracanan}


na avaliação de Teotônio, por um Congresso "desalentado, inoperante e inativo diante das decisões nacionais". A imagem desfigurada do Legislativo, em função da longa predominância do Executivo, precisava ser recomposta. Era urgente o encontro entre os dois poderes para, juntos, equacionarem o quadro institucional do país. Não por acaso, foi esse o sentido que Teotônio deu ao histórico encontro com o presidente Geisel, em março de 1975.

\section{O Quixote da transição democrática}

Se Gustave Doré vivesse no Brasil não precisaria quebrar a cabeça para desenhar o dom Quixote de Cervantes: bastaria ir ao Senado para descobrir na pessoa de Teotônio Vilela, imagem física quase igual à do famoso personagem (...) magro, seco, desengonçado, com quase dois metros de altura, possui para com a democracia o mesmo respeito e veneração que o Quixote pela sua Dulcinéia (...). Quando começou sua peregrinação pelo país, depois de demorada audiência com o presidente Geisel, Teotônio despertou iras e amuos (...); o homem de Alagoas não se intimidou, não recuou, não admitiu o silêncio cômodo de tantos outros. Foi chamado de "doido manso", pregador do impossível, mas sua lança continuou firme em direção ao futuro, moinhos de vento à parte.

O texto acima, do jornalista Carlos Chagas ${ }^{9}$, dá algumas pistas sobre o início da ascensão do senador alagoano ao pódio dos poucos políticos com voz ativa no processo de transição democrática deslanchado a partir do governo Geisel (1974-79). Previsto para durar 20 minutos, com o intuito de discutir a viabilidade do Proálcool, o encontro com Geisel acabou durando duas horas, e teria versado sobre o delicado tema do 'reordenamento democrático do país'. Em depoimento bem posterior a Márcio Moreira Alves ${ }^{10}$, Teotônio recordava:

O presidente Geisel me disse que a meta política do seu governo era o restabelecimento da democracia no Brasil. Não cabia a mim perguntar o que ele entendia por democracia, que limitações ou que salvaguardas queria impor para preservar o regime (...). Expus ao

Janeiro | Dezembro 2012 
presidente as minhas ideias e lhe disse que podia contar comigo para o que desse e viesse na sua luta pela restauração da democracia em nossa pátria. Ele ouviu e se limitou a fazer dois pedidos: que não me aproximasse do Paulo Brossard, que era o líder do MDB, e que não brigasse com o Petrônio Portela, que era o líder da Arena e que fora escolhido para negociar a abertura com a oposição. À saída, eu disse ao Geisel que seria fiel ao pensamento que ele me revelara e que só voltaria ao Palácio do Planalto se fosse expressamente chamado por ele. Ele não me chamou e eu nunca mais voltei.

Por que Geisel concordou que o quase desconhecido senador alagoano tivesse se apresentado como porta-voz dos seus planos de distensão política? Pode-se pensar no desejo do governo de avaliar o grau de resistência ou de aceitação desse projeto, evitando, assim, a exposição de 'notáveis' governistas. Desse modo, se a conjuntura política favoreceu a ascensão de Teotônio, este, por sua vez, não se fez de rogado. No dia 25 de abril, quase um mês depois do encontro com o presidente, proferiu um longo e aplaudido discurso no Senado, com o que ganhou as manchetes dos principais jornais do país. ${ }^{11}$

Foram quatro os principais pontos de sua proclamação aos senadores: 1) o impacto político do resultado eleitoral de 15 de novembro de 1974; 2) a função da Arena como garantidora dos compromissos da dita 'revolução' com a democracia; 3) os impasses da reordenação democrática corporificados na tensão entre segurança e liberdade, entre Estado de direito e Estado legal; 4) o papel decisivo do presidente Geisel como fiador do processo de abertura política.

Um dos seis senadores eleitos pela Arena, que sofreu fragorosa derrota nas eleições de 1974 - o MDB oposicionista elegeu 16 senadores -, Teotônio procurou se mostrar duplamente legitimado para se apresentar como porta-voz do projeto de distensão do presidente Geisel. Além de ter sempre pautado sua atuação política pela defesa dos princípios liberais, acabara de receber a preciosa aprovação popular vinda das urnas. Em sua avaliação, a Arena vivia um momento decisivo de sua vida como agremiação partidária. Em primeiro lugar, tinha que encarar a derrota de novembro e encontrar meios de reconquistar o eleitorado, lançando mão de um novo discurso e de novas práticas; de uma nova identidade, enfim. O sucesso de tal empreendimento

\section{Maracanan}


dependeria, no entanto, da maneira pela qual o partido iria se inserir no processo de redemocratização do país.

Para Teotônio, era chegada a hora dos políticos e dos partidos, que tinham diante de si a difícil missão de articular a transição 'pacífica' do autoritarismo para a democracia. A eles caberia, na encruzilhada em que se encontrava o país, enfrentar o desafio da esfinge: decifrá-la ou ser por ela devorado. Antes de tudo, a 'consolidação da segurança nacional' deveria ceder espaço à 'ordenação da liberdade'. Se muito tempo e investimento haviam sido destinados à primeira, as urnas de novembro haviam mostrado que agora era o momento de apostar na segunda. Mais do que o 'idealismo de dom Quixote', o que deveria contar naquela hora seria o 'realismo de Maquiavel'. Por isso mesmo, o senador arenista colocou também na mesa de debate a amplitude da abertura, pregando o rápido restabelecimento do Estado de direito, com a eliminação sumária do AI-5.

A reação de Geisel e da Arena ao discurso de Teotônio foi a mesma: o silêncio. O Jornal de Brasília, ao mesmo tempo em que anunciava a expressiva recepção da fala do senador alagoano - "Senado de pé aplaude Teotônio" -, registrava a ausência 'ostensiva', durante o discurso de Teotônio, dos vice-líderes da Arena, senadores Jarbas Passarinho e Virgílio Távora. ${ }^{12} \mathrm{O}$ presidente nunca mais recebeu Teotônio em audiência, nem sequer tocou no seu nome.

A resistência da Arena ao discurso de Teotônio Vilela pode ser atribuída a um conjunto de circunstâncias, dentre elas a pequena expressividade política e pessoal do representante de Alagoas naquele momento. Além do mais, não houvera nenhuma manifestação clara de Geisel reiterando o papel de porta-voz que Teotônio se auto-atribuía. Apesar do velho ditado que diz que quem cala consente, os arenistas não quiseram atender à conclamação do senador alagoano sem provas evidentes da sua condição de intérprete dos desígnios presidenciais. A falta de resposta do governo à fala de Teotônio parece indicar uma sintonia mais afinada com a atuação política de um outro senador nordestino. Se seus nomes curiosamente rimavam, se a origem regional e a antiga filiação udenista os aproximavam, eram diversos os projetos de Teotônio Vilela e do senador piauiense Petrônio Portela. Diversos, por exemplo, eram os prazos que previam para a abertura: se, para este, o fruto ainda tinha que amadurecer, para aquele, já estava passando do tempo de ser colhido. 
A estratégia escolhida pelo governo Geisel foi a da distensão 'segura, lenta e gradual', de modo a garantir a aceitação do processo por parte dos setores mais reticentes quanto à mudança da dinâmica política que até então presidira o regime militar. A redefinição do pacto de poder traz em si mesma a idéia de confronto, o que, no jargão militar, implica avanços, recuos táticos e, sobretudo, um pulso forte. Este deveria ser o do presidente da República, que não abria mão da liderança do processo, reservando-se a iniciativa de alterar o seu ritmo de acordo com as conveniências.

Em contraste com o silêncio constrangido das hostes governistas, o discurso de 25 de abril, uma sexta-feira tradicionalmente de pouco rendimento parlamentar, teve uma ruidosa divulgação nos principais jornais do país, os quais, logo no dia seguinte, abriram manchetes para anunciar o apelo do senador arenista em prol da 'rápida institucionalização do Brasil'. Além de destacar os principais pontos do longo discurso, a imprensa deu realce à maneira como as palavras de Teotônio foram recebidas, especialmente pelos senadores do MDB. O Estado de S. Paulo, por exemplo, enfatizou o enorme interesse despertado pelo discurso de Teotônio:

Durante uma hora e meia, o senador arenista prendeu a atenção dos 36 senadores e alguns deputados presentes ao plenário - número elevado para sexta-feira - não tendo recebido nenhum aparte durante o discurso. Ao final, foi mais aplaudido pela bancada do MDB que pela da Arena, tendo os oposicionistas passado dos aplausos a uma longa fila de cumprimentos (...). O senador Paulo Brossard [MDB], que durante quase todo o discurso meneava a cabeça em sinal de aprovação, e que o sucedeu na tribuna, considerou seu discurso "um dos mais importantes proferidos na presente sessão legislativa". ${ }^{13}$

A grande repercussão na imprensa do discurso de um senador de pequena expressão política pode ser explicada por um conjunto de fatores. Começando pelo tema tratado, a possibilidade de redemocratização do país. Passando pelo fato de que era um governista que encaminhava tal demanda. E terminando com o caráter fechado do regime, que parecia querer abrir uma porta em direção à sociedade. Começaria aqui o caso de amor de Teotônio com a imprensa, que logo percebeu a possibilidade de furar a censura a ela

\section{Maracanan}


imposta pelo regime ao publicar as 'veementes' declarações do senador 'dissidente' em favor da abertura. Portador de salvo-conduto por ser membro do partido do governo, o que o tornava, pelo menos em princípio, imune ao risco de cassação, Teotônio igualmente percebeu que a imprensa seria peça fundamental na sua sustentação política. Carente de apoio oficial, somente o espaço conquistado nos jornais e revistas seria capaz de lhe garantir a possibilidade de continuar falando e sendo ouvido.

De fato, Teotônio ganhou uma visibilidade até então só conquistada pelos notáveis do regime. O até então obscuro senador alagoano ganhou as honras de uma entrevista nas páginas amarelas da Veja, uma espécie de consagração olímpica do establishment nacional. ${ }^{14}$ Designado pelo Correio Braziliense, de 26 de junho, como "uma estrela em ascensão", Teotônio começou a receber uma torrente de convites para conferências, programas de TV e debates com estudantes universitários. Apesar da recepção fria que os interlocutores oficiais lhe devotaram, o empenho de Teotônio nos meses que se seguiram à famosa fala de abril se concentrou em garantir sua legitimidade como porta-voz de Geisel. Afinal de contas, fora essa condição, agora referendada pela imprensa, que lhe garantira olhos e ouvidos atentos, e era ela ainda a principal avalista do que continuava a pregar.

Essa 'legitimidade de porta-voz presidencial' foi seriamente atingida pelo discurso de Geisel em agosto, por ocasião da reabertura dos trabalhos legislativos de 1975. ${ }^{15}$ Nele, o general-presidente alertava que não se deveria confundir "distensão" (entre aspas) com distensão (sem aspas). A primeira, de caráter "meramente político", implicava "indisfarçável saudosismo pelo passado não muito remoto"; a outra, esvaziada de conteúdo político, se voltava prioritariamente para a dimensão social, ou seja, para o "progresso da nação e o bem-estar do povo".

O ano de 1975 terminou em outubro, com o alegado suicídio do jornalista Wladimir Herzog nas dependências do DOI-Codi de São Paulo. Nesse novo cenário, Teotônio deixou de ser o 'porta-voz presidencial', e passou a 'dissidente da Arena'. Como tal, ainda podia insistir na pregação em favor do Estado de direito, sem que, eventualmente, sobre ele pudesse cair o raio da cassação, embora, de maneira irônica, o vice-líder do governo, senador Eurico Rezende, a ele tivesse se referido como "o dom Hélder da Arena". ${ }^{16}$

O marco simbólico mais representativo dessa mudança foi a participação de Teotônio nos debates realizados no Teatro Casa Grande, situado na cidade 
do Rio de Janeiro. Em face do duro cerceamento de manifestações de caráter político, o uso de teatros como espaço aberto de discussão de temas considerados sensíveis tornou-se uma prática de resistência daqueles que lutavam pela redemocratização do país. No dia 13 de outubro, ao lado de Fernando Henrique Cardoso e dos jornalistas Prudente de Moraes Neto e Villas-Bôas Corrêa, Teotônio falou para um público de mais de 700 pessoas que se espremiam no teatro superlotado.

No dia 6 de novembro, com ampla cobertura da imprensa, Teotônio fez um balanço político de 1975, ano em que galgara a posição de estrela do cenário nacional. A expectativa pelo pronunciamento do 'rebelde' senador arenista crescera com o pesado clima de arbítrio e de insegurança que vigorava a partir do assassinato de Herzog um mês antes. Como perder a oportunidade de furar o bloqueio da censura, particularmente implacável depois desse episódio? A estratégia de Teotônio foi, por um lado, preservar a figura do presidente da República, já que considerava um erro político descredenciá-lo como promotor do processo, pois havia o risco de se perder a mais forte referência de possibilidade efetiva de redemocratização. Daí a pergunta que era quase uma acusação: "O presidente quer uma coisa, e quem quer outra?" Em outras palavras, quem estava colocando entraves e obstáculos às "saudáveis intenções políticas do principal chefe revolucionário?"17 Era evidente a tática de promover o descolamento de Geisel do que Teotônio chamava de 'Sistema', identificado como o 'quarto poder' que, a seu ver, detinha efetivamente o "controle dos mecanismos revolucionários". Desse 'Sistema', eufemismo para designar determinados setores encastelados nos órgãos de segurança ${ }^{18}$, partiriam as mais duras resistências ao processo de abertura, de que o dito 'suicídio' de Herzog seria uma prova irrefutável.

O MDB, fortalecido pela montanha de votos recebidos nas eleições de 1974, percebeu e aproveitou a oportunidade política oferecida pela atuação do 'oposicionista do governo'. O vice-líder do MDB no Senado, Roberto Saturnino Braga, declarou enfaticamente ter sido o discurso de Teotônio "o mais importante do ano". O apoio mais expressivo veio do próprio presidente do partido, Ulysses Guimarães que, em alto e bom som, declarou a respeito de Teotônio: "Falou certo e bem. Merece ser ouvido, meditado."19

Uma parte da Arena, da dita 'ala renovadora', percebeu igualmente que Teotônio abria possibilidades de fortalecimento da esfera partidária como lugar de

\section{Maracanan}


debate das decisões do governo, fora do ritual de obediência às determinações dos líderes arenistas ${ }^{20}$. $\mathrm{O}$ deputado paraibano Antonio Mariz, um dos principais nomes dessa ala, classificou o discurso de Teotônio como "uma excelente contribuição à luta pela institucionalização": "Vilela presta um excelente serviço quando coloca seu talento em defesa dessa causa, sem temor e correndo riscos." ${ }^{21}$

Os líderes arenistas, é certo, não escondiam o repúdio à postura adotada por Teotônio, considerada excessivamente crítica ao governo e ao partido do governo. No entanto, a expressão nacional que Teotônio havia conquistado trazia dividendos políticos para o partido, neutralizando, em parte do eleitorado, a imagem de uma agremiação em que só se permitia o elogio e o apoio às iniciativas oficiais.

Visto de hoje, pode parecer que Teotônio dizia o que queria porque teria as 'costas quentes'. É importante registrar, no entanto, que a expectativa de incolumidade parecia aos contemporâneos mais uma aposta do que propriamente uma certeza. Para os parlamentares que viveram aqueles anos incertos da abertura, o senador 'dissidente' não estava acima de qualquer suspeita a ponto de driblar os atos de exceção que cassavam mandatos e direitos políticos. Não por acaso, começou a se consolidar uma imagem de cavaleiro andante em relação a Teotônio, cuja aparência física favorecia, como vimos anteriormente, sua identificação com dom Quixote.

\section{Outras batalhas, outros moinhos}

Dono de um lugar todo especial dentro dos limites do restrito quadro político-partidário, Teotônio percebeu que poderia ampliar o escopo de sua atuação para além da esfera parlamentar. O ano de 1976, ao mesmo tempo em que registrou a cassação de dois deputados do MDB de São Paulo, acusados de pertencerem ao Partido Comunista Brasileiro (PCB), marcou o surgimento, no âmbito da sociedade civil, de movimentos mais amplos de contestação ao regime. Setores que até então haviam apoiado, ou pelo menos se mostrado pouco animados em atacar diretamente o governo militar, começaram a emitir sinais de reação ao que consideravam uma interferência demasiada do Estado nas esferas econômica e social.

Teotônio perceberia o vigor dessa mobilização, nela se engajaria, e dela se beneficiaria na medida em que passaria a ser identificado como uma ponte 
possível entre a sociedade política - como senador da Arena - e a sociedade civil. A necessidade de reajustes no modelo econômico, frente às dificuldades conjunturais que marcaram o fim do 'milagre' - a crise do petróleo foi a mais importante delas -, levou o empresariado a reivindicar uma presença mais efetiva nos espaços de tomada de decisão e nas arenas formais da política. Empresário do setor têxtil, o então ministro da Indústria e Comércio, Severo Gomes, se tornou um dos primeiros e mais chegados interlocutores de Teotônio. Conhecido por sua postura nacionalista em defesa do fortalecimento da classe produtora doméstica e da expansão do mercado interno, Severo era uma das vozes mais destacadas em favor da liberalização política, entendida como essencial para a prosperidade do setor econômico privado nacional.

Outra poderosa voz da sociedade civil que também clamava pela volta da democracia era a Igreja Católica. Com uma coordenação mais estreita na cúpula, através da Confederação Nacional dos Bispos do Brasil (CNBB), e uma participação mais ampla na base, por meio das Comunidades Eclesiais de Base (CEBs), a Igreja desenvolveu um intenso ativismo em defesa dos direitos humanos, denunciando prisões, torturas e assassinatos de opositores do regime militar. Essa militância ia mais além, na medida em que, atuando junto a áreas carentes, não se limitava ao trabalho de evangelização, incentivando e promovendo centros de discussão política. Não por acaso, o ano de 1976 registrou seguidos atos de violência contra o clero. ${ }^{22}$

Advogados e intelectuais, alvos privilegiados de qualquer regime autoritário, conseguiram, principalmente através de órgãos de classe como a $\mathrm{OAB}$ e a ABI, ou ainda por meio da criação de institutos de pesquisa financiados com recursos do exterior, como o Cebrap (Centro Brasileiro de Análise e Planejamento), construir espaços de resistência ao regime repressivo e áreas de articulação de projetos de redemocratização.

Jornais de grande circulação nacional, como O Estado de S. Paulo, Folha de S. Paulo e Jornal do Brasil, bem como a chamada imprensa alternativa representada por tablóides como o Pasquim, Movimento, entre outros, procuravam brechas possíveis por onde escapar da fina malha da censura diária. Isso pode explicar, em larga medida, o espaço generoso que um 'dissidente' conquistou nos jornais e revistas. Aproveitando como poucos esse espaço, Teotônio usou a mídia como um dos principais elementos de sua ascensão no panorama político nacional.

\section{Maracanan}


Em julho de 1976, Teotônio foi convidado para falar na sede da OAB do Rio Grande do Sul, em comemoração ao bicentenário da independência dos Estados Unidos. À medida que estendia seus laços para fora do âmbito parlamentar, mais ele enfatizava a importância de tornar o Estado permeável às reivindicações da sociedade. A necessidade de um 'diálogo nacional' foi o tema central de um debate organizado pela Folha de S. Paulo em setembro, com a participação de Teotônio e de mais um time de estrelas do jornalismo, como Cláudio Abramo, Boris Casoy, Alberto Dines e Mino Carta, entre outros. A rápida ascensão do senador no panorama político nacional foi destacada por um dos debatedores: "Há dois anos, 90\% da população de São Paulo jamais tinha ouvido falar no nome do senador; hoje, é uma figura relevante, convidado a fazer conferências em universidades de todo o país."

O ano de 1977, iniciado sob o signo do chamado "pacote de abril", ${ }^{23}$ se fecharia, em outubro, com a vitória do projeto de abertura arquitetado pelo governo Geisel, a partir da demissão do ministro do Exército, Sílvio Frota. Era chegada a hora de se colocar na mesa as propostas para a travessia rumo à redemocratização.

O chamado Projeto Brasil foi uma dessas propostas. Apresentada por Teotônio em abril de 1978, reunia um cardápio de sugestões quanto aos pontos 'essenciais e não negociáveis' com vistas à redemocratização - independência dos poderes; eleições diretas em todos os níveis; respeito às prerrogativas dos membros do Legislativo e do Judiciário; livre formação de partidos políticos; Constituinte -, bem como indicações para a mudança do modelo econômico que vinha enfrentando sérias dificuldades, como inflação em alta, concentração de renda, baixo consumo das massas, e mercado interno restrito.

Tachado de 'quixotesco', não se pode dizer que Teotônio houvesse incorporado exclusivamente a dimensão romântica e utópica que se costuma dar ao termo. Percebendo que a conjuntura de transição estava aberta a muitas possibilidades, procurou jogar alto, até mesmo blefar. Por que não pagar para ver a Constituinte, o fim do bipartidarismo, a anistia, a reformulação partidária, todas essas ditas "utopias" que, afinal, não demoraram a se realizar? Não é à toa que se diz que a política é um jogo de final imprevisível, muitas vezes em função de jogadores que ousam ir além dos limites determinados.

Libertada do AI-5, revogado em dezembro de $1978,{ }^{24}$ a sociedade brasileira começaria a se mobilizar com vistas ao restabelecimento da normalidade 
democrática. O cardápio inclúa anistia geral, ampla e irrestrita; eleições diretas para já em todos os níveis; Constituinte livre e soberana; reformulação partidária com a extinção do bipartidarismo; renascimento do movimento sindical, que já havia dados os primeiros passos nessa direção com a greve dos metalúrgicos do $\mathrm{ABC}$, que havia favorecido o surgimento de um novo líder, Lula, o metalúrgico.

Teotônio aproveitou a suspensão do instituto da fidelidade partidária para fins de filiação e, de maneira simbólica, ingressou no MDB no dia 25 de abril de 1979, quarto aniversário do famoso discurso sobre o projeto distensionista de Geisel, que acabaria por se transformar no ponto de partida de sua ascensão ao grupo de políticos que tinham vez e voz nos rumos do debate político no país.

As negociações políticas em torno da transferência de Teotônio para o MDB foram marcadas tanto pela ambiguidade da conjuntura política daquele início de 1979, quanto pelo perfil muito particular do senador alagoano. No que tange ao $\mathrm{MDB}$, a reorganização partidária prometida pelo governo, com o fim do bipartidarismo, era percebida como uma ameaça à 'unidade oposicionista'. Nesse caso, a decisão do senador alagoano de deixar a Arena parecia representar uma represália contra as insistentes investidas do governo destinadas a rachar o partido da oposição. Por outro lado, no entanto, havia a questão da ocupação de espaço dentro do MDB por um nome de expressão nacional como Teotônio, que carregava ainda a distinção de ter sido um dos principais construtores da abertura ora em curso. Em um partido de tantos caciques, qual seria o lugar a ele destinado ${ }^{25}$

Ao mesmo tempo, Teotônio, apesar da propagada 'afinidade de ideias', guardava certa reserva em ingressar no MDB. Sabia, por exemplo, que sua base de sustentação na política alagoana era majoritariamente oriunda da Arena. Como se pode deduzir de várias entrevistas que concedeu à imprensa, acreditava que o Projeto Brasil poderia aglutinar e dar forma a uma terceira legenda partidária, mais comprometida com o futuro pluripartidário do que com o passado do bipartidarismo. Consciente de que teria que construir uma trajetória própria no MDB como havia feito anteriormente na Arena, Teotônio sentiu-se à vontade para investir em causas mais conectadas com a sociedade civil, como a anistia para os presos e exilados políticos.

A escolha do presidente e do relator da Comissão Mista da Anistia foi um processo cuidadoso. O relator, indicado pelo governo, foi o deputado Ernani

\section{Maracanan}


Sátiro, ex-governador da Paraíba (1971-75), então presidente da Comissão de Constituição e Justiça da Câmara, conhecido por suas posições 'duras'. A presidência deveria ficar com um senador escolhido pelo MDB, e o partido indicou Teotônio, como 'uma saudação' pelo seu recente ingresso nas fileiras oposicionistas. $\mathrm{Na}$ verdade, na avaliação dos líderes emedebistas, esse era um assunto cuja discussão envolvia mais riscos do que ganhos políticos.

A estratégia escolhida por Teotônio para mobilizar a sociedade foi a das andanças pelo país, como já havia feito nos anos mais duros do governo Geisel. Em sua primeira reunião com o objetivo de colher subsídios para o substitutivo ao projeto de anistia do governo que o MDB pretendia apresentar ao Congresso, Teotônio reuniu um grupo expressivo de políticos, intelectuais e juristas. ${ }^{26}$ Dessa reunião, saíram propostas que se tornariam, a partir de então, a base das reivindicações da campanha em favor da uma anistia ampla, geral e irrestrita.

Fazendo valer sua tradição quixotesca de 'guerrilheiro da distensão', de 'doido manso', Teotônio visitou, no dia 10 de julho, junto com Fernando Henrique Cardoso e mais dois parentes de presos, o presídio do Barro Branco, em São Paulo, onde vários condenados por crimes políticos cumpriam pena. Em seguida, fez um relato dessa visita na ABI, onde se realizava uma manifestação pró-anistia organizada pelo Cebrade. ${ }^{27}$ No dia seguinte, Teotônio conversou, por mais de três horas, com os 15 presos políticos da Penitenciária Milton Dias Moreira, no Rio de Janeiro. ${ }^{28}$ A peregrinação pelos presídios continuou: no dia 18, a visita foi ao Barreto Campelo, em Recife, e no dia 19, ao Lemos de Brito, em Salvador. ${ }^{29}$

A mídia escrita, abrandados os rigores da censura prévia, acompanhava as andanças de Teotônio em favor da ampliação da anistia. Essa atuação, aliás bem pouco compatível com o cargo de presidente da Comissão da Anistia, rendeu-lhe, ao mesmo tempo, espaço qualificado no partido oposicionista, e críticas ácidas do ministro da Justiça, Petrônio Portela, que o acusou de ser 'doente por publicidade'. A pressão sobre Teotônio se acentuou. No dia 3 de agosto, logo em seguida à instalação oficial da Comissão Mista, recebeu uma notificação do general Reynaldo Mello de Almeida, presidente do Superior Tribunal Militar (STM), de que havia transgredido a resolução que disciplinava o regime carcerário, ao visitar, sem autorização prévia, presos condenados ou processados por crime contra a segurança nacional. Junto com o ofício 
do STM, Teotônio recebeu também uma carta do presidente do Senado, na qual este recomendava que se evitasse "qualquer quebra da harmonia que deve marcar as relações entre os altos poderes da República”. Instalada oficialmente, a Comissão da Anistia iria criar uma subcomissão com o objetivo de visitar os presos que, desde o dia 20 de julho, faziam uma greve de fome em protesto contra os limites e a demora da anistia.

Ao recusar o papel meramente formal de presidente da Comissão da Anistia, Teotônio assumiu, mais uma vez, a condição de interlocutor entre o Estado e a sociedade, e pôde construir uma determinada imagem de político preocupado com os 'direitos humanos', que iria se consolidar até a sua morte em 1983. Não por acaso, a comissão de direitos humanos que funciona junto ao Ministério da Justiça recebeu o nome de Comissão Teotônio Vilela de Direitos Humanos.

A dura repressão à greve dos metalúrgicos, em abril de 1980, foi analisada como um fato político que poderia colocar em risco o processo de abertura democrática. Mais do que uma 'guerra social' que se arrastava pelas ruas de São Bernardo sob a liderança de Lula, o que estava em jogo era a possibilidade de um golpe de Estado. ${ }^{30}$ Reafirmando os elementos que compunham seu perfil político, Teotônio, ao mesmo tempo em que usava a tribuna do Senado para denunciar "que o fato não era meramente social, mas eminentemente político", ${ }^{31}$ foi o único senador presente à assembléia dos metalúrgicos realizada na Igreja Matriz de São Bernardo, cercada pelas forças da repressão.

Nas cidades e no campo, a sociedade brasileira procurava se organizar e se mobilizar em busca de espaços de participação política negados pela política repressora da ditadura militar. Em agosto de 1981, 13 posseiros e dois padres franceses foram presos em São Geraldo do Araguaia e enquadrados na Lei de Segurança Nacional por "incitamento e ataque a agentes federais". Acompanhado dos deputados peemedebistas Jáder Barbalho (PA) e Cristina Tavares (PE), Teotônio foi visitar São Geraldo do Araguaia "para verificar a situação no próprio local". Apesar do ambiente tenso, já que a Polícia Militar fazia o controle de entrada e saída do povoado, os parlamentares falaram na igreja para mais de 300 pessoas. De volta a Brasília, Teotônio levou aos jornais as denúncias dos espancamentos a que familiares dos posseiros presos haviam sido submetidos, bem como do duro interrogatório imposto aos padres na sede da Polícia Federal, em Belém. ${ }^{32}$ Em maio de 1982, de volta do Araguaia,

\section{Maracanan}


mais uma vez em busca de solução para a situação dos padres e posseiros presos, Teotônio descobriu que estava com câncer.

"A política precisa de teotônios como os povos precisam de artistas."

Essa frase fechou o editorial da Folha de São Paulo, de 14 de novembro de 1983, dedicado a Teotônio Vilela, que viria a falecer duas semanas depois. Por que comparar a função dos artistas nas sociedades com a de 'teotônios' na política? A resposta, a meu ver, está conectada a uma tripla temporalidade - passado/ presente/futuro -, como, aliás, costuma acontecer no processo de construção de mitos e mitologias políticas. Girardet, por exemplo, ressalta o jogo sutil da sociedade com seus mitos, cujos surgimento e consolidação, sem dúvida, são favorecidos por momentos de mudança ou ruptura social. No entanto, longe de serem meras expressões dessas conjunturas, os mitos agem sobre a história; ao invés de uma falsificação arbitrariamente construída e imposta, encontram-se solidamente ancorados nas sociedades que os produzem. ${ }^{33}$

São conhecidos os estudos sobre o imaginário político nacional que abordam particularmente personagens em torno dos quais se cristalizaram poderosos impulsos de emoção, esperança e adesão, e que se tornaram, por isso mesmo, pontos de referência e núcleos de identificação coletiva. O sacrifício da própria vida em favor da causa da 'pátria' está presente, por exemplo, na construção de Tiradentes como herói da República brasileira em vias de consolidação ${ }^{34}$. Ou ainda, na conformação do mito Vargas, cuja vida teria sido oferecida em holocausto para "salvar a nação". 35

No caso de Teotônio, conforme acentuava o editorial da Folha acima citado, seu passado político já havia se transformado em 'saga'. Na qualidade de 'cidadão-senador', se descolara “da realidade das classes, dos partidos e dos interesses datados, para atingir outro terreno, o dos sentimentos perenes". Ao ingressar no território do mito, 'dos sentimentos perenes', Teotônio deveria continuar a repercutir no panorama brasileiro, no presente e no futuro.

O retorno a Alagoas, no início de agosto de 1982, após dois meses de tratamento de câncer em São Paulo, pode ser percebido como o primeiro momento de elevação de Teotônio à condição de 'santo cívico'. A começar pela calorosa recepção no desembarque no Aeroporto de Palmares, seguida pela repetição do gesto do papa João Paulo II de beijar o solo de Maceió. A 
pregação que fez em favor dos candidatos do PMDB nas eleições de novembro próximo, proclamando a necessidade do surgimento de "um outro Moisés que ajudasse a atravessar o Mar Vermelho", revestiu-se de um caráter claramente messiânico. ${ }^{36}$ Consolidava-se, naquele momento, a percepção de que o poder simbólico de Teotônio doente começava a se sobrepor à força do seu discurso político-eleitoral. Sua imagem de cabeça raspada, efeito da quimioterapia, sempre apoiado em uma bengala, tornou-se, ao mesmo tempo, símbolo da resistência na defesa da redemocratização, e de alerta para o país dos riscos de um 'câncer social'. Daí a decisão de retomar as andanças como "um cantador de viola, um menestrel". ${ }^{37}$ Salvação se tornou, então, palavra mágica - salvação para o país, a seu ver, à beira do desespero, ou pior, da desesperança.

Ao reunir o pessoal e o coletivo, a luta aberta de Teotônio contra o câncer foi percebida como uma metáfora das dificuldades por que passava a economia brasileira naqueles primeiros anos da década de 1980. A recessão era grave devido às severas medidas de ajustamento acordadas com o Fundo Monetário Internacional (FMI). O PIB caiu 2,8\%, e a produção industrial e o setor de serviços reduziram-se em 6,1\% e 5,3\%, respectivamente. A inflação não parou de aumentar - o IGP da Fundação Getulio Vargas registrou o índice de $211 \%$ para 1983 , enquanto o INPC, que corrigia os salários, apontou para o mesmo período a taxa de $178 \%$. Como se dizia à época, o país estava sendo acometido por uma 'doença' de nome estranho, 'a estagflação'.

A crise da dívida externa, que jogou o Brasil nos braços do FMI, favoreceu o estabelecimento de um tipo de identificação e de relação entre Teotônio doente e o 'país enfermo'. Apresentado como o 'homem providencial', elevado à condição de 'salvador da pátria', responderia, assim, às necessidades da sociedade brasileira naqueles tempos difíceis. No entanto, ao mesmo tempo em que exprimia o momento histórico vivido pelo país, Teotônio imprimiria sobre ele a sua marca.

Assumindo, novamente, o papel de porta-voz, dessa vez do PMDB, Teotônio lançou, em abril de 1983, um projeto destinado a 'salvar' o país, sugestivamente intitulado Projeto Emergência. O evento de lançamento na Comissão de Relações Exteriores da Câmara de Deputados contou com a presença de Ulysses Guimarães, presidente do partido, e de parlamentares de todos os partidos de oposição. A palavra-chave do programa emergencial

\section{Maracanan}


era 'dívida'. Como resgatar os diversos tipos de dívida que a ditadura havia acumulado ao longo de duas décadas? Para a mais urgente, a 'dívida externa', a solução apontada foi a moratória imediata. A 'dívida pública', contraída para financiar o déficit do governo, poderia ser equacionada mediante uma carga tributária mais pesada sobre os ganhos de capital e as grandes fortunas. Para a 'dívida social', a saída era a adoção de um programa de expansão do mercado interno e de distribuição de renda, tirando o país do incômodo lugar de recordista mundial de concentração de renda. Finalmente, a 'dívida política' seria resgatada com a convocação imediata de eleições diretas para presidente da República.

O 'grito de guerra' lançado por Teotônio não encontrou ressonância nos quadros técnicos do PMDB que, antevendo a concretização de seu projeto de poder após o governo Figueiredo, temia os efeitos devastadores que uma moratória poderia ter sobre a economia brasileira, tão dependente de recursos externos. Ao mesmo tempo, o PMDB sabia que a política precisa de 'teotônios', ainda mais em tempos marcados por alto grau de imprevisibilidade como aqueles em que as cartas da redemocratização ainda estavam na mesa. Apostando no tudo ou nada, Teotônio direcionou sua 'ira santa' contra políticos de seu partido que, temerosos das pressões da esquerda - uma passeata de desempregados havia derrubado, em abril de 1983, as grades do Palácio dos Bandeirantes -, procuravam o presidente Figueiredo em busca de uma transição democrática negociada com setores militares dispostos a aceitar um 'nome de conciliação'.

Acima do bem e do mal, Teotônio não vacilou em se lançar contra propostas conciliadoras que visavam evitar as tensões políticas decorrentes de um embate eleitoral para presidente da República em 1984. Por isso mesmo, dando continuidade à tradição 'quixotesca' que marcara sua trajetória política, colocou a realização das diretas como o ponto central a ser perseguido pelo PMDB. Na condição de presidente em exercício do partido, foi para Belo Horizonte conversar com o então governador Tancredo Neves. Intensamente aplaudido pelo público presente no aeroporto, reafirmou o compromisso histórico do PMDB com a escolha do presidente pelo voto popular. ${ }^{38}$

Carente de apoio de importantes setores do PMDB que preferiam uma 'política contemporizadora' longe das 'paixões radicais', Teotônio retomou a estratégia de promover uma grande mobilização da sociedade civil em defesa 
da eleição direta presidencial. Foi em busca do apoio de Lula, ${ }^{39}$ e de entidades como a ABI, a OAB, a CNBB, a UNE. Depois das eleições diretas para governador em 1982, o povo deveria voltar às ruas, e se mostrar capaz de protagonizar o processo de redemocratização em curso.

A canção O menestrel das Alagoas, composta por Milton Nascimento e Fernando Brandt em homenagem ao ex-senador Teotônio Vilela, foi lançada em setembro de 1983. Na voz de Fafá de Belém, se transformaria, ao lado de Coração de estudante, em um dos hinos da campanha das Diretas-Já, que tomou conta das principais cidades do país nos primeiros meses de 1984. Teotônio não chegou a ver as multidões nas ruas, pois havia falecido em Maceió poucos meses antes. No entanto, um enorme boneco, magro, de chapéu preto e bigodes compridos, era presença constante nas manifestações que então arrastaram milhões de brasileiros pelas ruas.

Nem Senhor Diretas como Ulysses, nem presidente que foi sem nunca ter sido, como Tancredo. Teotônio foi lembrado em recente artigo do jornalista Jorge Moreno para o jornal O Globo ${ }^{40}$ como o "doido manso" que "enquadrou" Leonel Brizola em uma reunião do PMDB que discutia os rumos da democracia brasileira, a comprovar que políticos que "carregam a história" fazem falta à política.

Maracanan 


\section{Notas e Referências}

1 Marly Silva da MOTTA. Teotônio Vilela. Brasília: Senado Federal, 1996.

2 Douglas Apratto TENÓRIO. A tragédia do populismo (o impeachment de Muniz Falcão). Maceió: EDUFAL, 1995.

3 Márcio Moreira ALVES. Teotônio, guerreiro da paz. Petrópolis: Vozes, 1983, p. 55.

4 Idem. p, 105

5 Marly Silva da MOTTA. Teotônio Vilela. Brasília: Senado Federal, 1996. Capítulo 4

6 Discurso de Teotônio Vilela no Senado Federal (10/04/1973), Diário do Congresso Nacional, 11/04/1973.

7 Discurso de Teotônio Vilela no Senado Federal (22/08/1973), Diário do Congresso Nacional, 23/08/1973. As citações seguintes foram extraídas do mesmo documento.

8 Grifo nosso.

9 Carlos CHAGAS. "A hora do doido manso". In: VILELA, Teotônio. A pregação da liberdade (andanças de um liberal), Porto Alegre: L\&PM Editores, 1977, s/p.

10 Márcio Moreira ALVES. Teotônio, guerreiro da paz. Petrópolis: Vozes, 1983, p.117.

11 Carlos CASTELlO BRANCO. “Tudo começou em abril”. In: VILELA, Teotônio. O libelo democrático. Brasília: Senado Federal, 1982, s/p.

12 Jornal de Brasília, 26/04/1975.

13 "Para arenista, 64 ainda é um compromisso a saldar", O Estado de S. Paulo, 26/04/1975.

14 Revista Veja, 18/6/1975.

15 “Distensão, a palavra-chave de Geisel na TV”, Jornal de Brasília, 02/08/1975. As citações seguintes foram tiradas do mesmo discurso de Geisel de 1 de agosto.

16 "Teotônio diz que distensão perde em conteúdo político", Jornal do Brasil, 15/08/1975.

17 Discurso de Teotônio Vilela no Senado Federal (06/11/1975), Diário do Congresso Nacional, 07/11/1975.

18 Maria Celina D'ARAÚJO, Glaucio Ary Dillon SOARES \& Celso CASTRO (orgs.). Os anos de chumbo: a memória militar sobre a repressão, Rio de Janeiro: Relume-Dumará, 1994. 
19 "Ulysses elogia fala de Teotônio Vilela", Diário de Brasília, 08/11/1975; "MDB entusiasmado com conceitos de Teotônio Vilela", Jornal de Brasília, 08/11/1975; “Teotônio deu patriótica contribuição, diz Ulysses”, Folha de S. Paulo, 08/11/1975.

20 Lucia GRINBERG. Partido político ou bode expiatório: um estudo sobre a Aliança Renovadora Nacional (Arena), 1965-79. Rio de Janeiro: Mauad, 2009.

21 “Teotônio deu patriótica contribuição, diz Ulysses”, op.cit.. Em 1982, Antonio Mariz ingressou no PMDB, sigla pela qual foi eleito senador em 1990, e governador da Paraíba em 1994.

22 Além dos assassinatos dos padres Rodolfo Lunkenbein e João Bosco Penido Burnier na região amazônica, em setembro houve o sequestro, seguido de espancamento, de dom Adriano Hipólito, bispo de Nova Iguaçu, na Baixada Fluminense.

23 Composto de 14 emendas e três artigos novos, além de seis decretos-leis, o "pacote" de abril, assim chamado pela imprensa, determinou, entre outras coisas, eleições indiretas para governador, com ampliação do Colégio Eleitoral; eleição de 1/3 dos senadores por via indireta (denominados pejorativamente "biônicos") e instituição de sublegendas, em número de três, na eleição direta dos restantes; extensão às eleições estaduais e federais da legislação restringindo a propaganda eleitoral no rádio e na televisão; alteração do quorum - de 2/3 para maioria simples — para a votação de emendas constitucionais pelo Congresso; nova composição do colégio eleitoral que elegeria o futuro presidente da República; e ampliação de cinco para seis anos do mandato presidencial.

24 No dia 20 de setembro, o Congresso aprovou por 241 votos contra 145 a Emenda Constitucional n 11. Entre outras medidas, a Emenda determinava a revogação do AI-5, o restabelecimento do habeas corpus para crimes políticos, a permissão para o reinício das atividades políticas dos cidadãos cassados havia mais de dez anos, o abrandamento das penas previstas na Lei de Segurança Nacional, e a suspensão por um ano do instituto da fidelidade partidária para fins de filiação ou formação de partidos. Ao mesmo tempo, contudo, era introduzida uma série de salvaguardas preservando o que se considerava 'autoritarismo do Executivo' que, por 120 dias, poderia decretar 'medidas de emergência', 'estado de sítio' ou 'estado de emergência', sem autorização expressa do Legislativo.

\section{Maracanan}


25 Ver os seguintes artigos: "Teotônio pode deixar seu partido em breve", Jornal de Brasília, 20/04/1979; "Vilela troca Arena pelo MDB", Correio Braziliense, 20/04/1979; "Arenista anuncia que deixará o partido", Jornal do Brasil, 21/04/1979; "A dúvida de Teotônio", Correio Braziliense, 22/04/1979.

26 Estiveram presentes Severo Gomes; Ulysses Guimarães, presidente do MDB; Mário Covas e Jarbas Vasconcelos, respectivamente presidentes da seção paulista e pernambucana do MDB; o suplente de senador, sociólogo Fernando Henrique Cardoso; os senadores Orestes Quércia e Lázaro Barbosa; o ex-ministro Almino Afonso; o ex-consultor-geral da República, Waldir Pires; os economistas Luciano Martins e José Serra, e os juristas Dalmo Dallari e Gofredo Teles.

27 "Presos pedem a Vilela anistia irrestrita", Folha de S. Paulo, 10/07/1979; “Presos vão rejeitar o indulto de Figueiredo", Jornal de Brasília, 10/07/1979.

28 "Teotônio Vilela visita 15 presos políticos no Rio", O Globo, 11/07/1979; "Vilela afirma que anistia é massa de manobra do governo", Folha de S. Paulo, 11/07/1979; "Vilela ouve presos do Rio", O Estado de S. Paulo, 11/07/1979.

29 "O fogo cerrado de Teotônio", Movimento, 22/07/1979.

30 "Teotônio teme que ocorra um golpe de Estado", Tribuna da Imprensa, 23/04/1980.

31 Discurso de Teotônio Vilela no Senado Federal (23/04/1980), Diário do Congresso Nacional, 24/04/1980. As citações seguintes foram extraídas do mesmo documento.

32 "Posseiros acusam violência policial (Teotônio ouviu depoimentos em São Geraldo do Araguaia)", Tribuna da Imprensa, 21/09/1981; "Vilela pede libertação de presos”, Folha de S. Paulo, 21/09/1981; “Teotônio denuncia entrega de terras a grandes empresas", Folha de S. Paulo, 22/09/1981.

33 Raoul GIRARDET. Mitos e mitologias políticas, São Paulo: Companhia das Letras, 1987.

34 CARVAlHO, José Murilo de. Os bestializados: o Rio de Janeiro e a República que não foi. São Paulo, Companhia das Letras, 1987.

35 Ângela de Castro GOMES. Apresentação. In: (org.). Vargas e a crise dos anos 50, Rio de Janeiro: Relume-Dumará, 1994.

36 Teotônio volta e beija solo alagoano, Folha de S. Paulo, 2/8/1982.

37 Jornal do Brasil, 10/10/1982. 
38 Teotônio assume a presidência do PMDB e condena tese do consenso, Folha de S.Paulo, 1/7/1983; Teotônio quer Tancredo na campanha da direta, $O$ Estado de S.Paulo, 2/7/1983.

39 Pleito direto une Teotônio e Lula, O Globo, 5/7/1983.

40 A santa ira de Teotônio Vilela, O Globo, 15/7/2012.

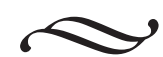

Maracanan 